\title{
LOCALIZATION OF NEUTRALIZING EPITOPES AND RECEPTOR-BINDING SITE IN MURINE CORONAVIRUS SPIKE PROTEIN
}

\author{
Fumihiro Taguchi, ${ }^{1}$ Hideyuki Kubo, ${ }^{1}$ Hideka Suzuki, ${ }^{1}$ and \\ Yasuko K. Yamada ${ }^{2}$ \\ ${ }^{1}$ National Institute of Neuroscience, NCNP \\ 4-1-1 Ogawahigashi, Kodaira \\ Tokyo 187, Japan \\ ${ }^{2}$ National Institute of Health \\ 4-7-1 Gakuen, Musashimurayama \\ Tokyo 190-12, Japan
}

\begin{abstract}
To identify the localization of the epitopes recognized by monoclonal antibodies (MAbs) against the $\mathrm{S} 1$ subunit of the murine coronavirus JHMV spike protein, we have expressed the $\mathrm{S} 1$ proteins with different deletions from the $\mathrm{C}$ terminus of the $\mathrm{S} 1$. All of MAbs in groups $\mathrm{A}$ and $\mathrm{B}$ recognized the $\mathrm{S} 1 \mathrm{~N}(330)$ composed of 330 amino acids (aa) from the $\mathrm{N}$ terminus of the $\mathrm{S} 1$ and the larger $\mathrm{S} 1$ deletion mutants, but failed to react with the $\mathrm{S} 1 \mathrm{~N}(220)$ composed of 220 aa. MAbs in group C reacted only with the Slutt protein without any deletion. These results indicated that the S1N330 comprised the cluster of epitopes recognized by MAbs in groups A and B. These results together with the fact that all the MAbs in group $B$ retained the high neutralizing activity suggested that the $\mathrm{N}$ terminus 330 aa are responsible for binding to the MHV-specific receptors. In pursuit of this possibility, we have expressed the receptor protein and examined the binding of each $\mathrm{S} 1$ deletion mutants to the receptor. It was demonstrated that the $\mathrm{S} 1 \mathrm{~N}(330)$ protein as well as other $\mathrm{S} 1$ deletion mutants larger than $\mathrm{S} 1 \mathrm{~N}(330)$ bound to the receptor. These results indicated that a domain composed of 330 aa at the $\mathrm{N}$ terminus of the $\mathrm{S} 1$ protein is responsible for binding to the MHV-specific receptor.
\end{abstract}

\section{INTRODUCTION}

Coronaviruses are enveloped, positive stranded RNA viruses associated with various diseases in both animals and humans ${ }^{1}$. The murine coronavirus (MHV) has a genome RNA of about 31 kilobases and encodes four major structural proteins: nucleocapsid protein, the 
integral membrane glycoprotein, the hemagglutinin-esterase glycoprotein and the spike (S) glycoprotein. Several non-structural proteins are encoded in the genome as well !

The spike comprises two to three molecules of the $\mathrm{S}$ protein of $150-200 \mathrm{KDa}$, each of which is a heterodimer consisting of two non-covalently bound S protein subunits, $\mathrm{S} 1$ and $\mathrm{S} 2$ derived from the $\mathrm{N}$-terminal and $\mathrm{C}$-terminal halves of the $\mathrm{S}$ protein ${ }^{1}$. The $\mathrm{S} 1$ subunit forms the globular head of the spike and the S2 its stalk portion ${ }^{2}$. The S protein of MHV is multifunctional. It attaches the virus to the cell surface by binding to MHV-specific receptors ${ }^{3}$. Although there are few reports concerning the analysis of the receptor-binding site on the $S$ protein, the topologies of the $S$ protein subunits suggest that the receptor-binding site is more likely to exist on S1 than on S2. The fusion of cultured cells infected with MHV is caused by the $\mathrm{S}$ protein ${ }^{4,5}$. The $\mathrm{S}$ protein is the major target of the neutralizing antibodies induced in mice after infection with MHV. It also elicits cytotoxic T cells ${ }^{6}$. Furthermore, the $S$ protein is suggested to be a major determinant of viral virulence in animals.

In this study, we showed that the cluster of epitopes recognized by MAbs with neutralizing activity were localized within 330 aa from the $N$ terminus of the $S 1$ subunit. Furthermore, we demonstrated that this $\mathrm{S} 1$ domain bound to the cellular receptor protein expressed by recombinant vaccinia virus (RVV).

\section{MATERIALS AND METHODS}

\section{Construction of the S1 Deletion Mutant Genes and Their Expression}

For expression of different $\mathrm{C}$ terminal deletions of the $\mathrm{S} 1$ protein we constructed various S1 genes that lacked successively longer segments from the 3' region. The S1NM, S1N, S1N(330), and S1N(220) genes encoding 594, 453, 330 and 220 aa from the $N$ terminus of the $\mathrm{S} 1$ gene were constructed by polymerase chain reaction (PCR); cl-2 S cDNA ${ }^{7,8}$ was template, the forward primer was a positive-sense oligonucleotide corresponding to the leader sequence of JHM and the reverse primers were oligonucleotides with nucleotides TTA complementary to the stop codon at the 5 ' end. We inserted the PCR products into $\mathrm{pCR}^{\mathrm{TM}} \mathrm{II}$ from the TA cloning kit. Each S1 gene was then cut out from the vector and the fragment was inserted into the vaccinia virus transfer vector (VV-TV), pSF7.5EB1-B5-12 (pSF) ${ }^{9}$. The VV-TVs with S1utt, S1NM, S1N, S1N(330) and S1N(220) were designated pSFS1utt, pSFS1NM, pSFS1N, pSFS1N(330) and pSFS1N(220), respectively. The S1 deletion mutant proteins were expressed by the infection of wild type VV and transfection of above VV-TVs (transient expression).

\section{Isolation of MHV-Specific Receptor Gene and Expression by RVV}

The RNA extracted from BALB/c liver was reverse transcribed into cDNA with oligo(dT)12-18 as a primer ${ }^{10}$. And the MHV receptor gene was then amplified by a pair of primers that correspond to the published nucleotide sequences of mmCGM1 around the initiation and termination codons ${ }^{11}$. The amplified fragment with a length of around 900-base pairs (bp) (mL900) was incorporated either in $\mathrm{pCR}^{\mathrm{TM}} \mathrm{II}$ vector or downstream of the $\mathrm{SR} \alpha$ promoter in the pcDL-SR $\alpha 296$ expression and cloning vector ${ }^{13}$. The $\mathrm{mL} 900$ was also inserted into the VV-TV, pSF. The RVV containing mL900 (RVV-MRe) was prepared as described previously ${ }^{8}$.

\section{Binding Assay of the S1 Mutant Proteins to MHV Receptor}

The lysates of RK13 cells infected with RVV-MRe were electrophoresed on SDSpolyacrylamide gel and transferred onto the transfer membrane paper as described pre- 
viously ${ }^{13}$. The membrane paper was incubated with the culture fluids from DBT cells producing S1 deletion mutants. The membrane paper was then washed and incubated with MAb No. 7. Binding of MAb No. 7 was estimated by enhanced chemiluminescence with horse radish peroxidase labeled anti-mouse IgG.

\section{RESULTS}

\section{Expression of the S1 Mutant Proteins in DBT Cells and Their Reactivities to a Panel of MAbs}

The MAbs specific for the S1 protein are classified into 3 different groups: those that react with most MHV strains (group A), those that specifically react with JHMV (group B), and those that specifically bind JHMV variants with the larger S protein (group C). All of these MAbs recognize conformational epitopes ${ }^{14}$. MAbs classified in group $\mathrm{C}$ do not react with the small S protein of sp- $4^{14,15}$. Cl-2 S1 protein consists of 769 aa, and that of sp-4 has a deletion of 141 aa which corresponds to aa 454 to 594 of $\mathrm{cl}-2$. Based on this difference of the S protein between cl-2 and sp-4, we designated three regions of the S1 protein S1N, S1M and S1C. The S1M region is missing in the small S protein of sp-4. The S1N and S1C regions correspond to the $\mathrm{N}$ terminal and $\mathrm{C}$ terminal regions as compared with the position of $\mathrm{S} 1 \mathrm{M}$. We constructed deleted $\mathrm{S} 1$ genes that expressed the S1NM $(\mathrm{S} 1 \mathrm{~N}+\mathrm{M})$ and $\mathrm{S} 1 \mathrm{~N}$ proteins as well as $\operatorname{S1N}(330)$ and $\operatorname{S1N}(220)$ which respectively encoded 330 and 220 aa from the S-protein $\mathrm{N}$ terminus. Each S1 deletion mutant was expressed in DBT cells by the VV transient expression system. For all the constructs, indirect immunofluorescence revealed that 5 to $10 \%$ of DBT cells produced the S1 protein. Western blotting analysis using the lysates prepared from such cells showed that almost equivalent amounts of S1 deletion mutants were produced in cells transfected with various pSFs and the sizes of the expressed $\mathrm{S} 1$ proteins were in accord with the sizes deduced from their gene structure. DBT cells expressing these species of $\mathrm{S} 1$ deletion mutants were examined for their reactivities to a panel of MAbs by indirect immunofluorescence. As shown in Table 1, all of the S1-specific MAbs reacted with the S1 utt which covered whole S1 protein ${ }^{16}$ in the same way as they did with the $\mathrm{S}$ protein produced in DBT cells by the infection of cl-2. All MAbs classified into groups A and B reacted to S1NM, S1N and S1N(330). Group C MAbs reacted only with S1utt and not with any other S1 deletion mutants. These results indicated that the epitopes recognized by MAbs in groups A and B are clustered in the S1 domain composed of 330 aa from the $\mathrm{N}$ terminus. And all the proteins, with the exception of the smallest protein expressed

Table 1. Reactivities of the S1-specific MAbs to the expressed S proteins*

\begin{tabular}{|c|c|c|c|c|c|c|c|c|c|c|c|c|c|c|}
\hline \multirow{3}{*}{$\begin{array}{l}\text { Recombinant } \\
\text { plasmid }\end{array}$} & \multicolumn{14}{|c|}{ Reactivity } \\
\hline & \multicolumn{3}{|c|}{ Group A } & \multicolumn{5}{|c|}{ Group B } & \multicolumn{6}{|c|}{ Group C } \\
\hline & 2 & 7 & 19 & 3 & 6 & 13 & 71 & 93 & 8 & 12 & 47 & 63 & 78 & 85 \\
\hline pSFSlutt & + & + & + & + & + & + & + & + & + & + & + & + & + & + \\
\hline pSFSINM & + & + & + & + & + & + & + & + & - & - & - & - & - & - \\
\hline pSFSIN & + & + & + & + & + & + & + & + & - & - & - & - & - & - \\
\hline pSFS1N(330) & + & + & + & + & + & + & + & + & - & - & - & - & - & - \\
\hline pSFS1N(220) & - & - & - & - & - & - & - & - & - & - & - & - & - & - \\
\hline
\end{tabular}

*The S1 deletion mutants proteins were expressed in DBT cells infected with VV after transfection with varıous $\mathrm{pSF}$ vectors The reactivities were examıned by indirect immunofluorescence 
by pSFS1N(220), form the same tertiary structure as does the entire S1 protein. Epitopes recognized by the MAbs in group $\mathrm{C}$ were not restricted to the $\mathrm{S} 1 \mathrm{M}$ region that is missing in the small $\mathrm{S}$ protein.

\section{Binding of S1 Deletion Mutants with MHv-Specific Receptor}

Most of the MAbs classified in group B showed very high neutralizing activity to $\mathrm{cl}-2^{14}$, which may suggest that these MAbs inhibit the binding of virus to the cellular receptor. If this is the case, the epitopes recognized by such MAbs or the adjacent regions to such $\mathrm{MAb}$ epitopes may play an important role in the binding of the virus to the receptor. In pursuit of this possibility, we examined the binding of the $\mathrm{S} 1$ deletion mutants to the receptor. By reverse transcription PCR, we isolated the gene encoding MHV receptor from mouse liver. The isolated MHV receptor was identical to $\operatorname{BgpC}$ or $\operatorname{MHVR}(2 \mathrm{~d})^{17}$. The expression of this protein in BHK21 cells rendered them susceptible to MHV infection as previously described $^{17}$. Cells infected with the RVV-MRe produced a few different species of receptor proteins; a major band was at $41 \mathrm{kDa}$ and a few additional bands were around $46 \mathrm{kDa}$. We then examined the ability of these proteins to bind various S1 deletion mutants. MHV-receptor-bound membranes were incubated with the lysates prepared from cells expressing S1 with the transmembrane domain (S1 tmd) or S2 with signal peptide (ssS2) ${ }^{16}$. The membrane paper was also incubated with culture fluids from cells producing the S1 deletion mutant proteins via a VV transient expression system; these S1 mutants lacked the transmembrane domain and therefore secreted mostly into the culture fluid. The binding of these S1 and S2 proteins were monitored with MAb No.7 and 10G, respectively. The S1 protein with a transmembrane domain bound to the $41 \mathrm{k}$ and $46 \mathrm{k}$ receptor protein, but binding of the $\mathrm{S} 2$ protein was indeterminant due to lack of reaction of MAb $10 \mathrm{G}$ even with the whole S protein bound to the receptor. The binding of the whole $\mathrm{S}$ protein could be easily detected by the $\mathrm{MAb}$ No.7. Fig. 1A shows that $\mathrm{S} 1 \mathrm{~N}(330)$ as well as the larger S1 proteins bound to the receptor, while $\mathrm{S} 1 \mathrm{~N}(220)$ apparently did not. $\mathrm{S} 1 \mathrm{~N}(220)$ may have bound the receptor, because MAb No. 7 used for the detection of various S1 deletion mutants failed to react with $\mathrm{S} 1 \mathrm{~N}(220)$. Also, MAb 11F recognizing the $\mathrm{N}$ terminal linear epitope of the $\mathrm{S} 1$ protein and reactive to all the $\mathrm{S} 1$ deletion mutant proteins failed to react with all the $\mathrm{S} 1$ mutants when

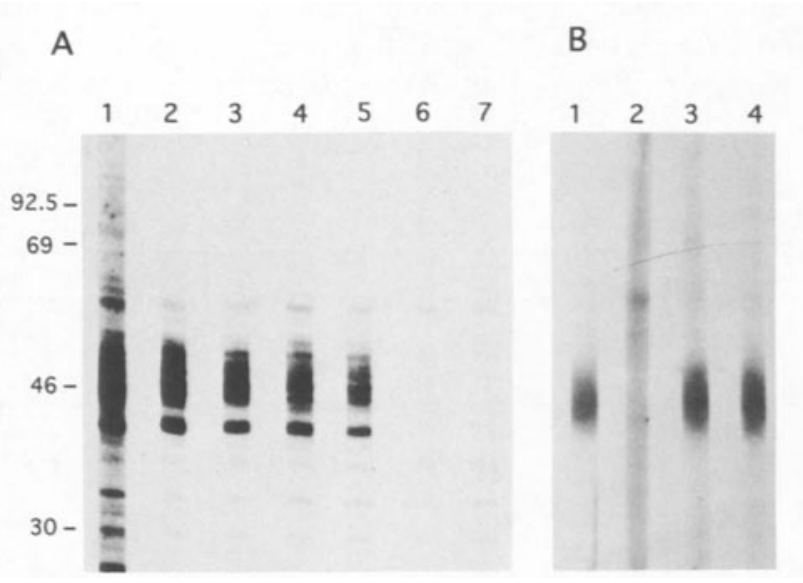

Figure 1. Receptor-binding of the $\mathrm{S} 1$ deletion mutants $(\mathrm{A})$ and inhibition of receptor-binding of $\mathrm{S} 1 \mathrm{~N}(330)$ by MAbs (B). (A): The MHV-receptor prepared on the membrane paper by Western blotting was reacted with the culture fluids of DBT cells infected with VV and transfected with pSFSlutt (2), pSFS1NM (3), pSFS1N (4), pSFSIN(330) (5), pSFSIN(220) (6) or mock transfected cells (7). The paper was then reacted with $\mathrm{S} 1$-specific MAb No. 7 and subsequently with peroxidase-labeled anti-mouse IgG. Lane 1 shows the position of MHV-receptor protein detected by anti-human CEA antibody. (B): The S1N(330) was mixed with neutralizing MAb No. 3 (2), non-neutralizing MAb No.2 (3), anti-N MAb No.5 (4) or PBS (1) and incubated at RT for $60 \mathrm{~min}$. These pretreated S1N(330) were monitored for their receptor-binding capacity as described in $\mathrm{A}$. 
these mutant $\mathrm{S} 1$ proteins bind to the receptor. At present, we have no way to see whether $\mathrm{S} 1 \mathrm{~N}(220)$ is capable of binding to the receptor. It was also evident from Fig. 1A that there was no striking differences in the amounts of the receptor-bound S1 mutant proteins except for $\mathrm{S} 1 \mathrm{~N}(220)$. These results clearly indicated that the region retained in the $\mathrm{N}$ terminal 330 aa of $\mathrm{S} 1$ protein is a major receptor-binding site in the $\mathrm{S} 1$ protein of MHV.

In order to examine the specificity of $\mathrm{S} 1 \mathrm{~N}(330)$ binding to MHV receptor, we have incubated the $\mathrm{S} 1 \mathrm{~N}(330)$ with neutralizing MAb No. 3 or non-neutralizing MAb No. 2, both of which are reactive to the $\operatorname{S1N}(330)$. The treated $\mathrm{S} 1 \mathrm{~N}(330)$ was then monitored for the binding to the receptor prepared on the membrane paper. As shown in Fig. 1B, the binding of the S1N(330) was perfectly inhibited by neutralizing MAb No. 3, while other non-neutralizing MAbs did not give any effect. These results clearly showed that the binding of the $\mathrm{S} 1 \mathrm{~N}(330)$ to MHV receptor was specific.

\section{DISCUSSION}

The $\mathrm{S}$ protein is known to be a multifunctional protein. However, very little is known about the relationship between biological functions and the structure of the $\mathrm{S}$ protein, except for the localization of neutralizing epitopes recognized by the MAbs ${ }^{18}$ and fusion activity by molecularly engineered S protein ${ }^{13}$. The $\mathrm{S}$ protein has long been assumed to be involved in receptor-binding. In this paper, we showed that the clusters of antigenic epitopes exist within 330 aa from the $\mathrm{N}$ terminus of the $\mathrm{S}$ protein. Furthermore, an $\mathrm{S} 1$ deletion mutant protein composed of the $\mathrm{N}$ terminal 330 aa of $\mathrm{S} 1$ bound to the MHV-specific receptor. This finding agrees with the idea that S1 comprises the bulbous portion of the characteristic club-shaped spike that is located in the outer extremity of the virion ${ }^{3}$.

Various S1 deletion mutants larger than $\mathrm{S} 1 \mathrm{~N}(330)$ bound to the receptor proteins without striking differences in intensity of binding. This excludes the possibility that some region in the $\mathrm{S} 1$, other than the $\mathrm{N}$ terminal 330 aa, is a major active site for receptor-binding. The antigenic epitopes recognized by group B MAbs are unlikely to be centers of receptorbinding sites, because these antigenic epitopes are specific for JHM strains and the receptors are known to serve as targets for JHM and A59 ${ }^{12,19}$. The MAbs in group B probably recognize the epitopes existing in the neighboring region of the receptor-binding site on the $\mathrm{S}$ protein and inhibit virus binding to the receptor by steric hindrance. The receptor also served as a binding site for some other MHV strains besides JHM (unpublished data) suggesting that the receptor-binding active site is conserved within 330 aa from the S1 N terminus in most MHV strains. We are currently determining the smallest, conserved, aa sequence that functions as a receptor-binding site.

Work on different coronaviruses suggests the involvement of the S2 subunit in receptor-binding activity; MAbs specific for the S2 of MHV have neutralizing activity 4 . However, the ability of S2 antibodies to neutralize virus may be the effect of steric hindrance, since the S protein is known to have a highly conformational structure ${ }^{1,3}$. Moreover, viral neutralization by antibodies does not always result from the prevention of virus binding to the receptor. When the S1 subunit of avian infectious bronchitis virus (AIBV) is removed, the virion is still able to bind susceptible cells, although it is not infectious ${ }^{20}$. This demonstrated that the S2 subunit mediates attachment. However, this attachment did not trigger the replication of attached viruses and would not be the genuine process that occurred with infectious virions retaining the S1 subunit. In the present study, we failed to demonstrate whether or not S2 bound to the receptor, because MAb 10G and others reactive to S2 in Western blot did not work for the detection of the receptor-bound S proteins.

In picornaviruses, a small canyon formed by the outer coat protein is proposed to be the precise location of receptor-binding; this idea is the so called canyon hypothesis ${ }^{21}$. 
Members of the immunoglobulin super-family serve as the receptors of these viruses ${ }^{22}$ The MHV receptors, mmCGM1 and mmCGM12 are also members of the 1mmunoglobulin superfamily There is another resemblance between picornavirus receptors and MHV receptors their $\mathrm{N}$ terminal domains, which are similar to the immunoglobulın variable region, are critical for interaction with viral proteins ${ }^{2324}$ The mechanism of MHV virus-receptor binding may be similar to that of picornaviruses Analysis of the receptor-binding site of the $\mathrm{S}$ protein will delineate the mechanism of virus-receptor interaction, which initiates virus infection

\section{REFERENCES}

1 Spaan,W, D Cavanagh, and M C Horzınek 1988 Coronaviruses structure and genome expression J Gen Virol 69 2939-2952

2 De Groot,R J, W Luytjes, M C Horzınek, B A M Van der Zeiıst, W J M Spaan, and J A Lenstra Evidence for a coiled-coil structure in the spike of coronaviruses J Mol Biol 196 963-966

3 Holmes,K V, E W Doller and J N Behnke 1981 Analysis of the function of coronavirus glycoprotein by differential inhibition of synthesis with tunicamycin Adv Exp Med Biol 142 133-142

4 Collıns,A R, R L Knobler, H Powell, and M J Buchmeier 1982 Mono-clonal antibodies to murine hepatitis virus-4 (strain JHM) define the viral glycoprotein responsible for attachment and cell fusion Virology 119 358-371

5 Vennema, H, L Hejnen, A Zıjderfeld, M C Horzıek, and W J M Spaan 1990 Intracellular transport of recombinant coronavirus spike proteins implication for virus assembly J Virol 64 339-346

6 Kyuwa,S, and S A Stohlman 1990 Pathogenesis of a neurotropic murıne coronavirus strain, JHM, in the central nervous system of mice Semin Virol 1 273-280

7 Taguchı,F, S G Siddell, H Wege, and V ter Meulen 1985 Characterızation of a varıant virus selected in rat brain after infection by coronavirus mouse hepatitis virus JHM J Virol 54 429-435

8 Taguchı,F, T Ikeda, and H Shida 1992 Molecular cloning and expression of a spıke protein of neurovirulent murıne coronavirus JHMV variant cl-2 J Gen Virol 73 1065-1072

9 Funahashi,S , S Itamura, S Innuma, H Nerome, M Sugımoto, and H Shida 1991 Increased expression in vitro and in vivo of foreign genes directed by A-type inclusion body hybrid promoters in recombinant vaccinia viruses J Virol $65 \quad 5584-5588$

10 Yamada, YK, M Abe, A Yamada, and F Taguch 1993 Detection of mouse hepatitıs virus by the polymerase chain reaction and its application to the rapid diagnosis of infection Lab Anım Sci 43 285-290

11 Dveksler,G S, MN Pensiero, C B Cardellıchı, R K Wıllıams, G Jiang, K V Holmes, and C W Diffenbach 1991 Cloning of the mouse hepatitıs virus (MHV) receptor expression in human and hamster cell lines confers susceptıbility to MHV J Virol 65 6881-6891

12 Takebe Y,M Seıkı, J Fuıısawa, J Hoy, K Yokota, K Ara1, M Yoshıda, and N Ara1 1988 SRa promoter an efficient and versatile mammalian cDNA expression system composed of the simian virus 40 early promoter and the R-U5 segment of human T-cell leukemia virus type 1 long terminal repeat Mol Cell Biol 8 466-472

13 Taguch,F 1993 Fusion formation by uncleaved spıke proteın of murine coronavirus JHMV variant cl-2 J Virol 67 1195-1202

14 Kubo,H , S Y Takase, and F Taguch 1993 Neutralızation and fusion inhibition activities of monoclonal antibodies specific for the S1 subunit of the spike protein of neurovirulent murine coronavirus JHMV cl-2 variant J Gen Virol 74 1421-1425

15 Taguchı,F and J O Flemıng 1989 Comparıson of six different murıne coronavirus JHM variants by monoclonal antıbodies against the E2 glycoprotein Virology 169 233-235

$16 \mathrm{Kubo,H}$, and F Taguchı 1993 Expression of the S1 and S2 subunits of murıne coronavirus JHMV spıke protein by a vaccinia virus transient expression system J Gen Virol 74 2373-2383

17 Dveksler,G S, C W Diffenbach, C B Cardellichı, K Mccuaıg, M N Pensiero, G S Jiang, N Beauchemın and K V Holmes 1993 Several members of the mouse carcinoembryonic antigen-related glycoprotein family are functional receptors for the coronavirus mouse hepatitıs virus-A59 J Virol 67 $1-8$

18 Luytjes,W, D Geerts, W Posthumus, R Meloen, and W Spaan 1989 Amıno acıd sequence of a conserved neutralızıng epitope of murıne coronaviruses J Virol 63 1408-1412 
19 Yokomorı, K, and M M C La1 1992 Mouse hepatitıs virus utllizes two carcionoembryonic antıgens as alternatıve receptors J Virol 66 6194-6199

20 Cavanagh,D , and P J Davis 1986 Coronavirus IBV removal of spıke glycopeptıde S1 by urea abolıshes infectivity and haemagglutınation but not attachment to cells J Gen Virol 67, 1442-1448

21 Rossmann,M G, E Arnold, J W Erıckson, E A Frankenberger, J P Griffith, H J Hecht, J E Johnson, G Kamer, M Luo, A G Mosser, R R Rueckert, B Sherry and G Vriend 1985 Structure of a human common cold virus and functional relationship to other picornaviruses Nature $317 \quad$ 145-153

22 Mendelsohn,C L, E Wimmer and VR Racaniello 1989 Cellular receptor for polıvirus Molecular clonıng, nucleotide sequence, and expression of a new member of the immunoglobulın superfamily Cell $56 \quad 855-865$

23 Dveksler, G S, M N Pensiero, C W Dieffenbach, C B Cardellıchio, A A Basile, PE Elia and K V Holmes 1993 Mouse hepatitıs virus strain A59 and blocking antireceptor monoclonal antibody bind to the N-terminal domain of cellular receptor Proc Natl Acad Sc1 USA 90 1716-1720

24 Koike,S , I Ise, and A Nomoto 1991 Functional domains of the poliovirus receptor Proc Natl Acad Sc1 USA 88 4104-4108 